\title{
Peningkatan Kesadaran Kesehatan Fetomaternal Menggunakan Deteksi Dini Kehamilan Berisiko Berbasis Optimalisasi Perangkat Lunak di Indonesia
}

\author{
Manggala Pasca Wardhana*1, Khanisyah Erza Gumilar ${ }^{2}$, Achmad Zam Zam Aghasy ${ }^{3}$ \\ 1,2Departemen Obtestri dan Ginekologi, Fakultas Kedokteran, Universitas Airlangga, Indonesia \\ ${ }^{3}$ Indonesian Health Collaboration and Innovation Institute (IHCI Institute), Indonesia \\ *e-mail: manggala.pasca@fk.unair.ac.id ${ }^{1}$, khanisyah@fk.unair.ac.id ${ }^{2}$, aghasy@ihci-institute.net ${ }^{3}$
}

\begin{abstract}
Abstrak
Kematian janin mendadak dalam kandungan merupakan sebuah tragedi bagi Ibu, keluarga maupun tim dokter yang menangani. Sekitar 98\% kejadian ini terjadi di negara berpenghasilan menengah hingga rendah, dan 2/3 kondisi ini terjadi di Asia Tenggara dan Afrika dimana Indonesia termasuk berada di dalamnya. Penurunan aliran darah plasenta dan gawat janin berhubungan dengan penurunan gerakan janin. Pengabdian masyarakat ini bertujuan untuk meningkatkan kesadaran kesehatan fetomaternal menggunakan deteksi dini kehamilan beresiko berbasis optimalisasi perangkat lunak di Indonesia. Metode kegiatan yang digunakan dalam kegiatan ini adalah webinar daring, dengan pengukuran peningkatan wawasan menggunakan pre and post test dengan peserta wanita usia subur. Aplikasi yang dikembangkan untuk menghitung pergerakan janin dalam kandungan dalam kegiatan ini adalah TIMANG (Fetal Diary on Movement and Activity Counting) yang dikembangkan oleh tim pengabdian kepada masyarakat Universitas Airlangga dan Tim IHCI Institute. Aplikasi ini berfungsi sebagai catatan harian aktivitas bayi dalam kandungan trimester 3. Informasi dari aplikasi ini dapat digunakan sebagai deteksi dini permasalahan janin di dalam kandungan. Kagiatan ini didapatkan hasil bahwa peserta mengalami peningkatan setelah mengikuti acara pengabdian masyarakat ini.
\end{abstract}

Kata kunci: Aplikasi Kehamilan, Ibu dan Anak, Ibu Hamil, Intrauterine Fetal Death, Kematian Janin

\begin{abstract}
Sudden fetal death in the womb is a tragedy for the mother, family, and the team of doctors who treat it. About $98 \%$ of these events occur in middle to low-income countries, and 2/3 of these conditions occur in Southeast Asia and Africa where Indonesia is included. Decreased placental blood flow and fetal distress are associated with decreased fetal movement. This community service aims to increase awareness of fetomaternal health using early detection of high-risk pregnancies based on software optimization in Indonesia. The activity method used in this activity is an online webinar, with measurements of increased insight using pre and posttests with female participants of childbearing age. The application developed to calculate fetal movements in the womb in this activity is TIMANG (Fetal Diary on Movement and Activity Counting) which was developed by the Airlangga University community service team and the IHCI Institute Team. This application serves as a daily record of baby activities in the 3rd trimester of pregnancy. Information from this application can be used for the early detection of fetal problems in the womb. This activity showed that the participants experienced an increase after participating in this community service event.
\end{abstract}

Keywords: Fetal Death, Intrauterine Fetal Death, Mother and Child, Pregnancy Application, Pregnant Mother

\section{PENDAHULUAN}

Kematian janin mendadak dalam kandungan merupakan sebuah tragedi bagi Ibu, keluarga maupun tim dokter yang menangani. Sekitar 6 dari 1000 kelahiran atau 3.2 juta kematian janin terjadi setiap tahunnya. 98\% kejadian ini terjadi di negara berpenghasilan menengah hingga rendah, dan 2/3 kondisi ini terjadi di Asia Tenggara dan Afrika dimana Indonesia termasuk berada di dalamnya (Lawn et al., 2009). Di masa pandemi COVID-19 terjadi peningkatan kematian janin yang cukup signifikan dibandingkan dengan sebelum pandemi. Di inggris, peningkatan tersebut sebesar $4 \mathrm{x}$ lipat dibanding sebelum pandemi dan penelitian yang lebih besar di Nepal menyebutkan peningkatan sebesar 50\% (Knight et al., 2020; Watson, 2020). 
Peningkatan tersebut bukan karena infeksi virus yang menyerang ibu hamil melainkan akibat dari pembatasan terhadap pelayanan kesehatan.

Berdasarkan Survei Demografi dan Kesehatan Indonesia tahun 2012, tidak ditemukan penurunan angka kematian neonatal dengan survei sebelumnya yang dilakukan pada tahun 2007 yaitu 19/1000 kelahiran hidup. Faktor yang mempengaruhi kejadian kematian janin dalam kandungan dapat berasal dari ibu, janin, maupun plasenta Kondisi ibu seperti usia dan penyakit yang diderita, serta kejadian ketuban pecah dini dapat menyebabkan kematian mendadak janin (Kemenkes RI, 2013). Salah satu upaya untuk mencegah terjadinya kematian pada janin adalah dengan melakukan pemeriksaan kandungan minimal 4 kali: satu kali pada saat trimester I dan II serta dua kali pada trimester III. Pengetahuan ibu mengenai tanda bahaya pada kehamilan serta konsumsi makanan yang bergizi selama kehamilan dapat membantu dalam pencegahan kematian janin (Maslovich \& Burke, 2020; Menezes et al., 2009; Society of Maternal Fetal Medicine., 2020). Pengetahuan tersebut akan sangat bermanfaat bagi ibu dan keluarga di rumah guna peningkatan kesehatan ibu serta janin, terutama dengan adanya pembatasan akses ke pelayanan kesehatan di masa pandemi COVID-19.

Sekitar 55-63\% kematian janin dalam kandungan didahului dengan pergerakan janin yang menurun dan dirasakan oleh ibunya. Penurunan aliran darah plasenta dan gawat janin berhubungan dengan penurunan gerakan janin (Efkarpidis, Alexopoulos, Kean, Liu, \& Fay, 2004; Heazell et al., 2017; Warland et al., 2015). Konsep penghitungan gerakan janin sangat rasional karena mudah, tidak membutuhkan alat canggih dan dapat dilakukan oleh semua wanita, yaitu dengan menghitung seberapa banyak gerakan janin tiap harinya. Pengambilan keputusan yang tepat dari adanya penurunan gerak janin ini dapat membantu upaya penurunan angka kematian janin dalam kandungan secara signifikan (Bekiou \& Gourounti, 2020; Koshida et al., 2021; Tveit et al., 2009). Salah satu upaya meningkatkan pengetahuan ibu mengenai kesehatan ibu dan janin terutama terkait perhitungan gerakan janin di masa pandemi COVID-19 adalah dengan memberikan edukasi melalui kegiatan webinar online. Tujuan dilaksanakan kegiatan ini adalah untuk meningkatkan kesadaran kesehatan fetomaternal menggunakan deteksi dini kehamilan beresiko berbasis optimalisasi perangkat lunak di Indonesia.

\section{METODE}

Webinar daring ini memiliki topik Menjaga Kesehatan Ibu dan Janin Bersama Aplikasi TIMANG. Dilaksanakan pada Minggu 15 Agustus 2021 pukul 09.00 melalui Platform Zoom Meeting dan Youtube. Narasumber pada webinar ini adalah seorang ahli di bidang fetomaternal, staff pengajar Departemen Obstetri dan Ginekologi FK Universitas Airlangga, sekaligus salah satu pendiri aplikasi TIMANG, yaitu Manggala Pasca Wardhana, dr., Sp.OG (K). Aplikasi Timang merupakan sebuah aplikasi untuk memudahkan ibu dalam melakukan perhitungan gerakan janin sebagai salah satu bentuk upaya menurunkan angka kematian janin/bayi. Aplikasi ini dikembangkan oleh IHCI Institute bersama dengan dr. Manggala Pasca Wardhana, Sp.OG (K) dan Komunitas Materna Matter.

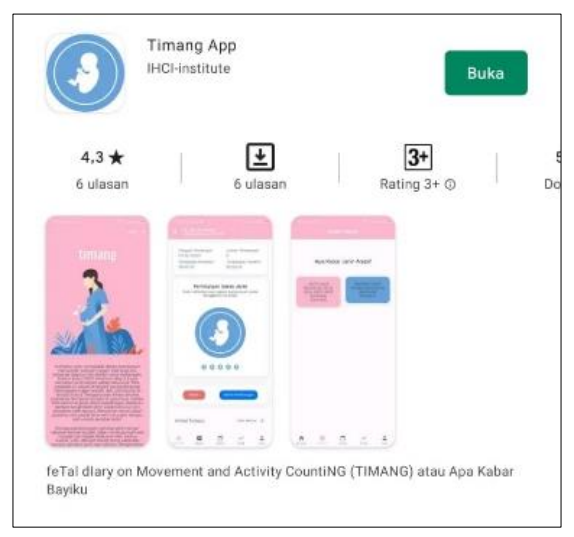

Gambar 1. Tampilan Timang app 
Tujuan dari webinar ini adalah: (a) mengkampanyekan dan memberikan edukasi bagaimana menjaga kesehatan ibu hamil dan janin kepada kelompok masyarakat digital di Indonesia; (b) Mengkampanyekan dan memberikan edukasi penggunaan Aplikasi Timang sebagai alat untuk mengamati aktivitas bayi dalam kandungan pada trimester ketiga atau 28 minggu; dan (c) Untuk melihat peningkatan pengetahuan peserta, peserta diberikan pertanyaan seputar kesehatan ibu dan janin melalui aplikasi timang sebelum dan sesudah acara webinar (pre - post test).

Sebelum mengikuti webinar, para peserta diharuskan mengisi link pendaftaran sekaligus pengisian pre-test yang berisi pertanyaan seputar Kesehatan ibu dan janin, perhitungan gerakan janin, dan aplikasi TIMANG. Webinar ini terbagi menjadi 2 sesi, sesi 1 adalah pemaparan materi Menjaga Kesehatan Ibu dan Janin, seperti hal-hal yang perlu ibu hamil periksakan ke tenaga kesehatan yang berwenang. Kemudian pada sesi 2 menjelaskan bagaimana cara menghitung gerak janin baik secara manual maupun menggunakan aplikasi Timang sekaligus pengenalan aplikasi TIMANG beserta demonstrasinya. Setelah pemaparan materi selesai, peserta diharuskan mengisi link post-test yang berisi pertanyaan serupa dengan pre-test.

Data karakteristik peserta ditampilkan secara deskriptif. Nilai pre dan post test akan ditampilkan secara deskriptif untuk melihat peningkatan nilainya. kemudian nilai pre-post test akan dibandingkan menggunakan uji komparasi Wilcoxon sign rank test jika data berdistribusi tidak normal atau uji paired $\mathrm{T}$ test jika data berdistribusi normal untuk mengetahui perbandingan nilai sebelum dan sesudah diberikan materi.

\section{HASIL DAN PEMBAHASAN}

Peserta yang mengikuti kegiatan ini berjumlah 200 peserta dan tersebar dari berbagai daerah di Indonesia (Provinsi Aceh hingga Provinsi Nusa Tenggara Barat), baik ibu hamil maupun ibu yang tidak hamil. Materi yang disampaikan dalam Webinar ini berjudul "Menjaga Kesehatan Ibu dan Janin Bersama Aplikasi Timang". Susunan acara Webinar diantaranya adalah pembukaan oleh pembawa acara, peserta mengisi link pre-test, selanjutnya moderator memandu berjalannya webinar, pembacaan CV narasumber oleh moderator, sesi 1 pemaparan materi Menjaga Kesehatan Ibu dan Janin, sesi 2 penjelasan dan perkenalan aplikasi Timang, diskusi antara peserta dengan narasumber, pembagian link post-test kepada peserta, pembagian doorprize, penutupan webinar oleh pembawa acara.

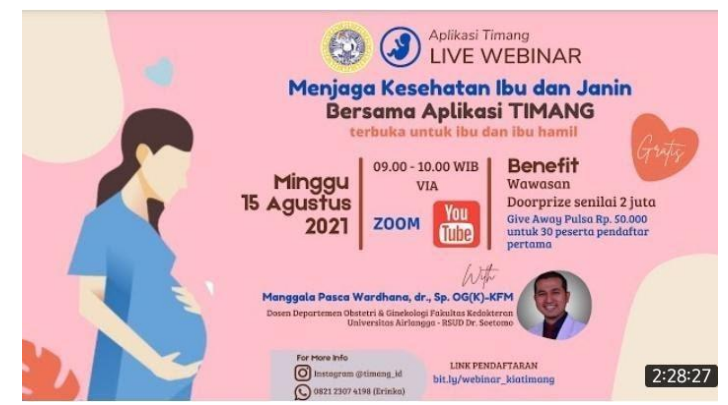

Gambar 2. Poster Webinar Timang

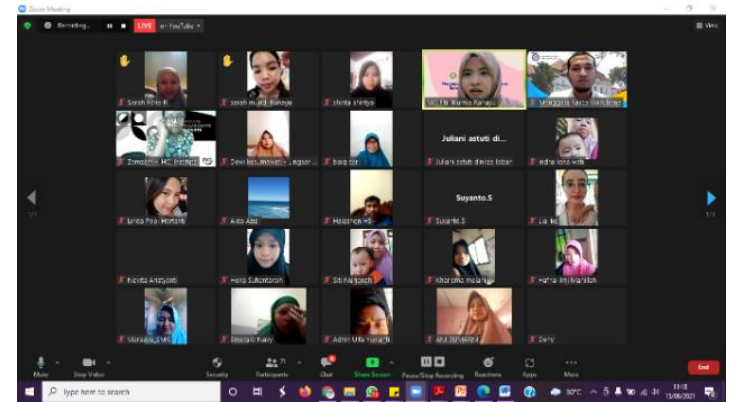

Gambar 3. Kegiatan Webinar 
Dari 200 peserta yang mengikuti webinar, sebanyak 75 peserta yang mengisi pre-test dan post-test secara lengkap yang akan ditampilkan secara deskriptif dan statistik. Data karakteristik responden bisa dilihat pada tabel 1 yang menunjukkan bahwa mayoritas responden berusia $\leq 25$ tahun yaitu sebanyak 34 (45.3\%) responden. Responden yang ikut serta dalam diskusi mayoritas tidak hamil yaitu sebanyak 57 (76\%) responden. Responden yang hamil mayoritas saat ini hamil pertama yaitu $17(22.7 \%)$ responden. Pendidikan terakhir responden terbanyak adalah SMA yaitu sebanyak 39 (52\%) responden sedangkan terendah adalah SMP yaitu 1 (1.3\%) responden. Pendapatan keluarga tertinggi adalah $\geq$ Rp. 4,500,000 yaitu sebanyak 50 (66.7\%). Mayoritas responden sering mencari info di internet yaitu 63 (84\%) responden.

Tabel 1. Karakteristik Responden

\begin{tabular}{|c|c|c|}
\hline Karakteristik Responden & Frekuensi (n) & Persentase (\%) \\
\hline \multicolumn{3}{|l|}{ Usia Responden } \\
\hline$\leq 25$ tahun & 34 & 45.3 \\
\hline 26-45 tahun & 14 & 18.7 \\
\hline$\geq 46$ tahun & 27 & 36.0 \\
\hline \multicolumn{3}{|l|}{ Usia Kehamilan } \\
\hline Tidak hamil & 57 & 76 \\
\hline Trimester Pertama & 6 & 8 \\
\hline Trimester Kedua & 6 & 8 \\
\hline Timester Ketiga & 6 & 8 \\
\hline \multicolumn{3}{|l|}{ Kehamilan ke } \\
\hline Belum hamil & 56 & 74.7 \\
\hline Hamil pertama & 17 & 22.7 \\
\hline Hamil kedua & 2 & 2.7 \\
\hline \multicolumn{3}{|l|}{ Pendidikan Terakhir } \\
\hline SMP & 1 & 1.3 \\
\hline SMA & 39 & 52.0 \\
\hline D3 & 7 & 9.3 \\
\hline S1 & 26 & 34.7 \\
\hline S2 & 2 & 2.7 \\
\hline \multicolumn{3}{|l|}{ Pendapatan Keluarga } \\
\hline$<$ Rp. $4,500,000$ & 25 & 33.3 \\
\hline$\geq$ Rp. $4,500,000$ & 50 & 66.7 \\
\hline \multicolumn{3}{|l|}{ Rutinitas mencari info } \\
\hline Jarang & 10 & 13.3 \\
\hline Sering & 63 & 84.0 \\
\hline Tidak pernah & 2 & 2.7 \\
\hline Total & 75 & 100 \\
\hline
\end{tabular}

Untuk grafik skor pre dan post test peserta dapat dilihat pada Gambar 4 dan Gambar 5 ditunjukkan dengan skor pretest terbanyak dengan nilai 87 dan skor post-test terbanyak dengan nilai 93. Terlihat bahwa terdapat peningkatan wawasan peserta sebelum dan sesudah mengikuti kegiatan (Gambar 6). Sedangkan rerata peningkatan wawasan responden yang mengikuti kegiatan adalah 6.20 (Tabel 2). Namun demikian tidak terdapat perbedaan yang signifikan setelah dilakukan pengujian menggunakan paired T Test (p-value: 0.074, Tabel 3). Secara umum, pengetahuan awal yang dimiliki responden menunjukkan skor yang relatif tinggi dengan rerata $75.69 \%$, yang dapat diasumsikan bahwa 8 dari 10 responden telah memiliki wawasan yang sudah cukup baik. Setelah mendapatkan materi dan dilakukan post test terdapat peningkatan rerata skor wawasan menjadi $81.89 \%$. Kegiatan ini, secara khusus mengangkat topik gerakan janin sebagai fokus utama, dan berdasarkan notulensi yang didapatkan dalam aktivitas diskusi dan tanya-jawab, responden mendapatkan pengetahuan baru mengenai gerakan janin dan penggunaan aplikasi TIMANG dalam deteksi dini gangguan pada kesehatan janin. 
Frekuensi Skor Pre Test

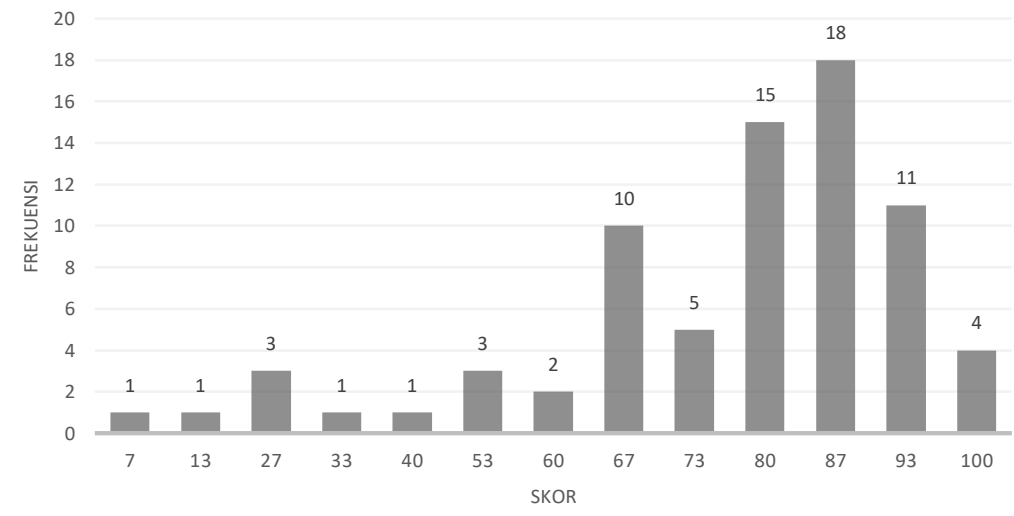

Gambar 4. Grafik Skor Pre Test

Frekuensi Skor Post test

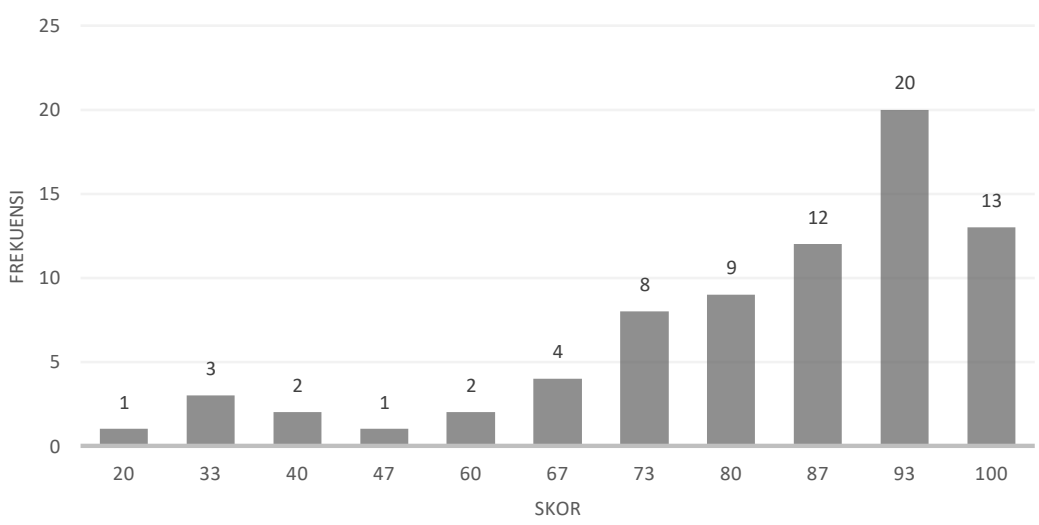

Gambar 5. Grafik Skor Post Test

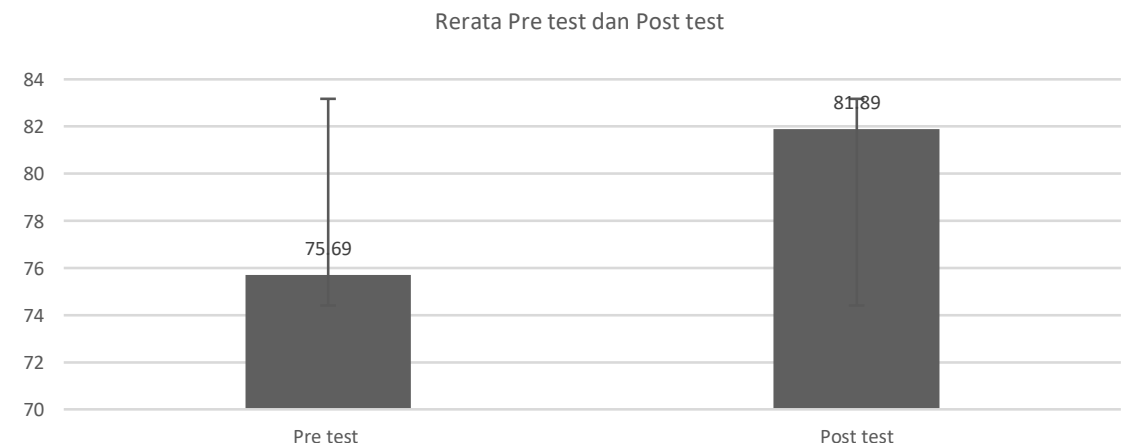

Gambar 6. Grafik Rerata Skor Pre Test dan Post Test

Tabel 2. Rerata dan Simpangan Baku Peningkatan Wawasan Responden

\begin{tabular}{cccc}
\hline & Rerata & Simpangan Baku \\
\hline Peningkatan Wawasan & 6.20 & 29.637 \\
\hline \multicolumn{4}{c}{ Tabel 3. Pengujian Statistik Skor Pre Test dan Post Test } \\
\hline Pre test - Post test & $-13.019-0.619$ & $t$ & Sig. \\
\hline
\end{tabular}




\section{KESIMPULAN}

Kegiatan ini didapatkan hasil bahwa peserta mengalami peningkatan wawasan setelah mengikuti webinar Menjaga Kesehatan Ibu dan Janin Bersama Aplikasi Timang, dibuktikan bahwa hasil rerata peningkatan wawasan adalah 6.20 .

\section{DAFTAR PUSTAKA}

Bekiou, A., \& Gourounti, K. (2020). Reduced Fetal Movements and Perinatal Mortality. . Mater Socio Medica, 32(3), 227.

Efkarpidis, S., Alexopoulos, E., Kean, L., Liu, D., \& Fay, T. (2004). Case-control study of factors associated with intrauterine fetal deaths. MedGenMed., 6(2), 53.

Heazell, A., Warland, J., Stacey, T., Coomarasamy, C., Budd, J., Mitchell, E., \& Al., E. (2017). Stillbirth is associated with perceived alterations in fetal activity - findings from an international case control study. BMC Pregnancy Childbirth., 17(1), 1-11.

Kemenkes RI. (2013). Survei Demografi dan Kesehatan Indonesia 2012. BPS - BKKBN.

Knight, M., Bunch, K., Vousden, N., Morris, E., Simpson, N., Gale, C., \& Al., E. (2020). Characteristics and outcomes of pregnant women admitted to hospital with confirmed SARS-CoV-2 infection in UK: National population based cohort study. BMJ, 369(7), 2020-1.

Koshida, S., Tokoro, S., Katsura, D., Tsuji, S., Murakami, T., \& Takahashi, K. (2021). Fetal movement counting is associated with the reduction of delayed maternal reaction after perceiving decreased fetal movements: a prospective study. Sci Rep, 11(1), 11-6. https://doi.org/doi.org/10.1038/s41598-021-90240-4

Lawn, J., Yakoob, M., Haws, R., Soomro, T., Darmstadt, G., \& Bhutta, Z. (2009). 3.2 million stillbirths: Epidemiology and overview of the evidence review. BMC Pregnancy Childbirth., 9(suppl 1), 1-17.

Maslovich, M., \& Burke, L. (2020). Intrauterine Fetal Demise; . Available. William Sparrow Hospital: StatPearls Publishing, Treasure Island (FL). Retrieved from http://europepmc.org/abstract/MED/32491465

Menezes, E. V., Yakoob, M., Soomro, T., Haws, R., Darmstadt, G., \& Bhutta, Z. (2009). Reducing stillbirths: Prevention and management of medical disorders and infections during pregnancy. BMC Pregnancy Childbirth., 9(1), 1-49.

Society of Maternal Fetal Medicine. (2020). Obstetric Care Consensus: Management of stillbirth delivery. Obstet Gynecol, 135(3), E110-132.

Tveit, J., Saastad, E., Stray-Pedersen, B., Børdahl, P., Flenady, V., Fretts, R., \& Al., E. (2009). Reduction of late stillbirth with the introduction of fetal movement information and guidelines - A clinical quality improvement. BMC Pregnancy Childbirth, 9(1-10).

Warland, J., O’Brien, L., Heazell, A., Mitchell, E., Collins, J., Huberty, J., \& Al., E. (2015). An international internet survei of the experiences of 1,714 mothers with a late stillbirth: The STARS cohort study. BMC Pregnancy Childbirth., 15(1), 1-11.

Watson, C. (2020). Stillbirth rate rises dramatically during pandemic. Nature, 585(7826), 490-1. 